\title{
LOOKING BACK: AN INVERTED TELESCOPE AND AN OBLIQUE GAZE
}

\author{
Joshua Barker
}

The late Benedict Anderson was one of a handful of scholars in the social sciences whose work was read across the disciplines and across the world. His most well known book was, of course, Imagined Communities, a key text for political scientists, anthropologists, historians, and students of comparative literature. ${ }^{1}$ Anderson was more than a generalist, however. He got his start in Southeast Asian studies and throughout his life continued to produce fascinating studies of literature, culture, and politics in the region. His first book, Java in a Time of Revolution, based on his doctoral dissertation, analyzed the role played by Javanese youth in the Indonesian revolution. ${ }^{2}$ It was published in 1972 and remains the benchmark study of the Indonesian revolutionary struggle. He wrote numerous essays on Southeast Asia, with special attention given to Indonesia, Thailand, and the Philippines. These essays range from studies of literature and culture, to studies of modernity, nationalism, and the state.

When people ask me why I have chosen to spend more than two decades of my life visiting and studying a country to which I have no particular familial or historical connection, I often point to Anderson's 1972 essay, "The Idea of Power in Javanese Culture." 3 For myself, as for many others, "The Idea of Power" was Anderson's most

Joshua Barker is Associate Professor, Department of Anthropology, University of Toronto.

1 Benedict Anderson, Imagined Communities: Reflections on the Origin and Spread of Nationalism (London: Verso, 1983; rev. and exp., 1991, 2006).

2 Java in a Time of Revolution: Occupation and Resistance, 1944-1946 (Ithaca: Cornell University Press, 1972).

${ }^{3}$ Benedict Anderson, "The Idea of Power in Javanese Culture," in Culture and Politics in Indonesia, ed. Claire Holt (Ithaca: Cornell University Press, 1972). 
generative piece of work prior to Imagined Communities. In Indonesian studies it served as an inspiration and a foil for the works of many subsequent scholars, including Clifford Geertz's Negara: The Theater State, Shelly Errington's Power and Meaning in a Southeast Asian Realm, Koentjoeraningrat's voluminous works on Javanese culture, Ward Keeler's Javanese Shadow Plays, Javanese Selves; Anna Tsing's In the Realm of the Diamond Queen, John Pemberton's On the Subject of Java, and Danilyn Rutherford's Laughing at Leviathan, among many others. ${ }^{4}$ In works by Wolters, Errington, and Cannell, Anderson's account of Java came to be seen as one local variant of what was a wider Southeast Asian style of culturally constructing power and polities. ${ }^{5}$ In Indonesian and Southeast Asian studies, this text was thus critical to what later came to be referred to more broadly as "the interpretive turn" in the social sciences.

I encountered "The Idea of Power" in the same way that I encountered the music of the Beatles: at the point where it was being re-released for retro consumption. On the back of my copy of Language and Power: Exploring Political Cultures in Indonesia, published in 1990, Joe Errington's blurb noted that the essays within would provide "an intellectual chronology of a major Southeast Asianist and social theorist" who is "largely unknown to the wide audience Anderson now commands." 6 In other words, it was a volume aimed at all the people who had read Imagined Communities and knew nothing of Anderson's Southeast Asianist roots. Although I first read "The Idea of Power" some two decades after it was first published, this sprawling essay captured my imagination by opening up an alternate political universe - ascribed to "Java"where the laws of political meaning were off-kilter and nothing was what it seemed.

In the Introduction to The Spectre of Comparisons, Anderson describes the feeling that he got when he first started comparing Indonesian politics to European politics. ${ }^{7}$ He says he "felt a kind of vertigo" because "it [was] the first time in [his] young life that he had been invited to see [his] Europe through an inverted telescope" (p. 2). Anderson's work always produces that kind of vertigo, particularly for those who know something about the topics on which he writes. It is an effect he produces in a variety of ways. He does it through comparison: not just by seeing Europe through the inverted telescope of Java, but by seeing Java through Europe, the Philippines through Indonesia, and the United States through Thailand. But he also does it by working across disciplinary boundaries: by seeing politics through the inverted telescope of culture, literature through politics, history through literature, and culture through

${ }^{4}$ Clifford Geertz, Negara: The Theatre State in 19th Century Bali (Princeton: Princeton University Press, 1981); Shelly Errington, Power and Meaning in a Southeast Asian Realm (Princeton: Princeton University Press, 1989); R. M. Koentjoeraningrat, Javanese Culture (Oxford: Oxford University Press, 1989); Ward Keeler, Javanese Shadow Plays, Javanese Selves (Princeton: Princeton University Press, 1987); Anna Lowenhaupt Tsing, In the Realm of the Diamond Queen: Marginality in an Out-of-the-Way Place (Princeton: Princeton University Press, 1993); John Pemberton, On the Subject of "Java" (Ithaca: Cornell University Press, 1994); and Danilyn Rutherford, Laughing at Leviathan: Sovereignty and Audience in West Papua (Chicago: University of Chicago Press, 2012).

${ }^{5}$ Oliver Wolters, History, Culture, and Region in Southeast Asian Perspectives (Ithaca: Cornell Southeast Asia Program Publications, 1999); Shelly Errington, Meaning and Power in a Southeast Asian Realm (Princeton: Princeton University Press, 2014); and Fenella Cannell, Power and Intimacy in the Christian Philippines, Vol. 109 (Cambridge: Cambridge University Press, 1999).

${ }^{6}$ Benedict R. O'G. Anderson, Language and Power: Exploring Political Cultures in Indonesia (Ithaca: Cornell University Press, 1990).

${ }^{7}$ Benedict Anderson, The Spectre of Comparisons: Nationalism, Southeast Asia, and the World (London: Verso, 1998). 
history. His masterful use of this technique-together with his elegant use of the essay form-is what allowed him to share with his readers his own feeling of vertigo.

Of course, Anderson was not alone in making a decentering vertigo the hallmark of his work. Many great thinkers of the late-twentieth century did just that. Yet there are a couple of things that set his work apart. First, he achieved the decentering effect not simply through cunning tricks of light and language. His writing does not create a hall of mirrors whose sole purpose is to disorient. Rather, he fixes his telescope on the realm of observable and verifiable facts in an attempt to bring the closest foreground and the deepest background into focus simultaneously. In other words, his work decenters not through a move toward theoretical abstraction so much as through a deepening of empirical context in unexpected and unusual ways. It thus compels us not to wonder at his theoretical marvels but to search deeper into the world of facts. Another thing that distinguishes Anderson's work from that of many of his contemporaries is that he grounded his decentering project in familiar terrain. He denaturalized concepts and ideas everyone could understand and with which most people could identify: the idea of the nation, the idea of power, and the idea of community, to mention a few examples.

The thrust of Anderson's essay on "The Idea of Power" fit well with the times. He described the essay as having been "written directly out of [his] fieldwork in Java between 1961 and 1964. Composed at a time of "Western triumphalism" at having gotten rid of President Sukarno, its mood was," he noted, "indigenist and nationalist." 8 It spoke to the possibility that Indonesian modernization could follow an alternative path that built upon its precolonial history. Anderson aimed "to describe the picture of social and political life seen through traditional Javanese lenses, and to draw explicit contrasts with the pictures seen through the lenses of modern social science." It was a recuperative essay in the anthropological mode, showing how the apparently "irrational" appeal of Sukarno made sense when set against the background of the rationality of traditional Javanese thought. For Anderson, making sense of this appeal was also a way of recuperating the revolutionary potential of charisma. He believed that this potential was most manifest not in a universal teleology, but in localized forms, such as Mao in China or Sukarno in Indonesia. He saw such leaders as being driven by history, rather than as leading history. He faulted Weber for allowing the true power of charisma to remain obscure as a result of his either sticking it in the historical past or treating it as an abstract, trans-historical force, but without reference to a broader social context. He lamented the loss of its redemptive association. ${ }^{10}$

One of the most interesting, and perhaps underappreciated, qualities of Anderson's thought was the way it circled back on problems. In the mid-1980s he wrote another essay, which later appeared in Language and Power alongside the "Idea of Power," called "Further Adventures of Charisma." While the title suggests a sequel to the earlier paper, the relationship between the two is not so straightforward. Rather than a linear progression of his argument, the paper highlights aspects of the theory of

${ }^{8}$ Anderson, "The Idea of Power," 11.

9 Ibid., 18.

10 Ibid., 77.

11 Benedict Anderson, "Further Adventures of Charisma," in Anderson, Language and Power, 78-93, based on the paper "The Discourse of Charisma," for the American Anthropological Association, 1985. 
$4 \quad$ Joshua Barker

charisma that had been overlooked in "The Idea of Power." Specifically, he wants to show why charisma as a concept was necessary, both for Weber and for contemporary social science. For Weber, as Anderson saw it, it was necessary both because of his aspirations for a universal, teleological history, and because of his liberal desire to retain the hope of freedom; and for twentieth century liberal social science it was necessary because it served an essentially ideological function, obscuring the real machinery of state violence, which was the administrative rationality of the modern state.

When I first read this sequel, I took it as a kind of ambivalent reversal of his earlier argument. Whereas previously he had been intent on showing the continued relevance and reality of charisma, now he was arguing that the belief in charisma only served to throw into shadow the violent and authoritarian dimensions of the infrastructure of the modern state. In his Introduction to Language and Power, Anderson puts it differently, saying that "Further Adventures" is a consideration of the implications of his earlier paper in light of Imagined Communities. But he also says something else: that he thinks each of the papers contains a partial truth, but he has yet to see how the essays can be linked. Rereading them both today, I am struck by how the later paper is not so much an elaboration of his earlier ideas as a circling back on the same problem, but from a different perspective, which foregrounds dimensions of the problem that could not be seen from the vantage point of the earlier, more relativist approach.

The relationship between the two essays reminds me of the relationship between the first (1983) and second editions (1991) of Imagined Communities. There, too, the subsequently appended chapters on "Map, Census, Museum," and "Memory and Forgetting," stand in an oblique relation to the previous text, throwing light on a different dimension of national imaginings that was not visible from the earlier vantage point. In both cases an earlier story of youthful political enthusiasm with a hopeful open-endedness is tempered by a colder, more mature realism about the unseen structures that variously constitute, constrain, represent, and undermine the open-ended potential of these youthful forces.

Viewed from a wider angle, one can see a similarly oblique, cross-perspectival relationship between the set of works written in the 1980s (Imagined Communities and "Further Adventures") and the works written in the late-sixties and published in the early seventies (i.e., Java in a Time of Revolution and "The Idea of Power"). James T. Siegel has pointed out the strange fact that Imagined Communities somehow manages to tell the story of the origins and spread of nationalism without ever discussing revolution. ${ }^{12}$ This oversight seems odd for someone whose first major work was a study of the Indonesian revolution. But another way of looking at this is to see it as Anderson's tendency to circle back to an old problem to see it from a new vantage point that exposes earlier blind spots. While Anderson made much of the comparative method and the forms of revelation it made possible, his use of this oblique perspective was equally integral to his analytical approach.

If we circle back, we can reflect upon the circumstances that gave rise to, or at least gave space for, Anderson's remarkable sociological imagination. The most obvious was what, in retrospect, has come to seem like a somewhat naïve embrace of

12 See Siegel's accompanying essay in this issue of Indonesia. 
anticolonial nationalism. As Anderson puts it in his introduction to Language and Power, "Perhaps it was out of an inverted Orientalism, but my sympathies, like those of many of my fellow Southeast Asianists, were then strongly with the nationalisms of the region."13 Looking back, it is easy to underestimate the power that the political struggles of the Third World had for observers of Asia and Africa in that period. I have some sense of it because my father was a political scientist of sub-Saharan Africa, and as a young child in Toronto in the early 1970s I felt, first-hand, the energy of the meetings, parties, and fundraisers for the Toronto Committee for the Liberation of Southern Africa. There was an optimism and excitement as people from North America and Europe learned about, and became engaged in, the struggles against colonialism and neocolonialism unfolding in Asia and Africa.

The situation with respect to Indonesia was somewhat unusual in this regard. Sukarno had clearly provoked this kind of enthusiasm among many observers, and, under the leadership of George Kahin, Cornell University, where Anderson was based, had by the mid-1960s become the leading center for research on the country. Those who were there at the time, including Anderson, Ruth McVey, and James Siegel, have all described this period as one in which people with an interest and with deep knowledge about Indonesia were invited to join Cornell's Indonesianist community. Many of these people were not, or did not see themselves as professional academics. This was evident in the journal Indonesia, which they founded in 1966. Its content and form expressed the ethos of the Indonesianist group: a kind of serious and intellectually rigorous amateurism, open to an eclectic mix of translations, reports, reviews, and articles. ${ }^{14}$

Cornell in the 1960s was-like many campuses-a hotbed of activism, and anthropological thinking about social change resonated deeply with the zeitgeist. For a time, Victor Turner taught at Cornell, and Siegel remembers how his lectures on liminality and rites of passage drew overflow crowds from across the university. Anderson and the others were not themselves of the 1960s baby-boom generation; they were the young teachers of this cohort. Although the instructors participated in activist struggles, they also brought a more seasoned perspective to bear on them. The other side of this activism was an intense division at the university, as students, faculty members, and administrators divided along political lines, in regards to both the civil rights movement and the Vietnam War. I studied anthropology at Cornell in the 1990s, and the social and political chasms that had opened up in that department in the sixties and early seventies were still the main fault lines that we, as students, had to learn to navigate. For Indonesianists, the politics surrounding the Vietnam War were particularly acute, since Indonesia was very much at play within the Southeast Asian theater of Cold War confrontation. It was within this context that "The Idea of Power" was written, and it is partly against this backdrop that its interest in charisma and revolution should be understood.

By the same token, the circling back in "Further Adventures of Charisma" needs to be understood in the dual context of what was happening in Indonesia and what was happening in academia. In Indonesia, of course, there was General Suharto's pre-

${ }^{13}$ Anderson, Language and Power, 7.

${ }^{14}$ See Indonesia 100 (October 2015) for retrospective essays by Anderson, McVey, Siegel, and others. 
emptive coup, the massacres, and the long consolidation of New Order authoritarian rule. While the intrigues surrounding the coup could readily be interpreted from within a Cold War frame, the massacres were much harder to assimilate. Anderson later wrote that "it felt like discovering that a loved one is a murderer." 15 It is worth pausing on that statement for a moment to let it sink in.

My own reading is that while Anderson's empathetic capacity to get inside and express to his readers the understanding that comes with adopting different vantage points came from his earlier experiences, including his experiences in Sukarno's Indonesia and Cornell's turbulent 1960 s, his inability to leave problems behind, and his compulsion to circle back on them from a new, oblique perspective, came from his experience of the massacres. Having fallen in love with one that turned out to be a murderer, he learned to second-guess his enthusiasm and the blinds spots it might create.

For Anderson, the gradual decline of the sociological imagination in area studies could be explained by the growing professionalization of academia. He noted on many occasions that almost none of that early Cornell group of scholars was, in fact, credentialed, and in the fiftieth anniversary issue of Indonesia last fall (October 2015), shortly before his death, he took aim at the way so many academic journals have increasingly come to churn out such standardized professional fare. Undoubtedly, this awareness of the hidden dangers of modern bureaucratic rationalization for scholarship also informed his wish to revisit and recuperate the revolutionary potential of charisma.

Whether today we have the conditions for the emergence of a new kind of sociological imagination I am not sure. Academic professionalization is more intense than ever, but the divides between Asia, Africa, and the rest of the world are again breaking down in interesting ways. From my dual vantage points in Toronto and Bandung, it seems to me that it is at the edges of the university, where scholars are interfacing with nonacademic researchers, activists, and retirees, where much of the more creative and imaginative work is taking place.

In the introduction to Language and Power, Benedict Anderson described the book's theoretical ambition as an effort "to link the splendors of the imagining life with the remorseless engines of global economic and technological change." 16 More than ever, this remains the challenge for those generations of Southeast Asianists that Anderson has left behind.

15 Anderson, Language and Power, 7.

16 Ibid., 8. 